\title{
NEUTRON DIFFRACTION STUDIES
}

by
C. G. Shull
E. O. Wollan
M. C. Marney

Oak Ridge National Laboratory

This document is reproduced as a project report and is without editorial preparation. The manuscript has been submitted to The Physical Review for possible publication.

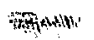

Date Declassified: September 29, 1948

Issuance of this document does not constitute

Twathority for declassification of classified

copies of the same or similar content and title and by the same authors.

Technical Information Branch, Oak Ridge, Tennessee AEC, Oak Ridge, Tenn., 4-I1-49-850-A1462

The

PUDLICLY TEISASAEL

He Kiasm

Ambriziag Cốciut

D.w: 24105 $\therefore$ PRINTED IN U.S.A。

PRICE 5 CENTS NECHCAL LIBRARY

TECHNICAL LIBRARM IOFIION BRANCH. ORE 


\section{DISCLAIMER}

This report was prepared as an account of work sponsored by an agency of the United States Government. Neither the United States Government nor any agency Thereof, nor any of their employees, makes any warranty, express or implied, or assumes any legal liability or responsibility for the accuracy, completeness, or usefulness of any information, apparatus, product, or process disclosed, or represents that its use would not infringe privately owned rights. Reference herein to any specific commercial product, process, or service by trade name, trademark, manufacturer, or otherwise does not necessarily constitute or imply its endorsement, recommendation, or favoring by the United States Government or any agency thereof. The views and opinions of authors expressed herein do not necessarily state or reflect those of the United States Government or any agency thereof. 


\section{DISCLAIMER}

Portions of this document may be illegible in electronic image products. Images are produced from the best available original document. 


\title{
NEUTRON DIFHRACTION STUDIES
}

\author{
By C. G。 Shull, E。O.Wollan and M。C.Marrey
}

\section{SCATTERING CROSS SECTION AND PHASE OF SCATTERTNG FOR Ni58 AND Ni60}

Various scatering cross-section determinations for $\mathrm{Ni}$ have indicated a much larger scattering than suggested by simple potential scattering. Normel nickel contains two major isotopes, Ni58 (68.0\%) and $\mathrm{Ni} 60(27.2 \%)$, along with the minor isotopes $\mathrm{Ni} 61, \mathrm{Ni} 62$, and $\mathrm{Ni} 64$. In attempting to assign the anonalous scattering crose section to a particular isotope, samples of $\mathrm{N} 55^{\circ}$ and $\mathrm{N} 160 \mathrm{O}$ were obtained from the Isotopes Production Division at $Y-12$ and were examined in the neutron diffraction spectromster.

Figure I shows the diffraction patterns obtained for the three nickel oxide preparations consisting of $\mathrm{N} s 8^{2}, \mathrm{~N} i 60$, and normel $\mathrm{N} 1$. The experimental data for the three samples have been corrected for specimen weight, absorption, ete, so that the patterns are directiy comparable. Since nickel oxide crystallizes in the NaCl-type face centered cubic structure, a comparison of the (111) and (200) Intensities permits a direct determination of the phase of scattering of the nickel isotopes. It is seen In Figure 1 inat the (200 reflection is stronger than the (I1) reflection for all three specimens, and hence it follows that Ni58, $\mathrm{Ni} 60$, and elemental N1 scatter neutrons with positive phase, the samo as does oxygen... It is also seen that the patterns differ markediy in intensity, signifying that the seattering cross sections are widely different. From the measured intensitises of the diffraction park; the coherent scattering cross sections for $\mathbb{N} 58, \mathrm{NI} 60$, and elemental $\mathrm{Ni}$ have been determined as 27, 2, and 14 barns respectively. Since poteritial scattering accoralrg to the physical size of these nuclei should contribute a scattering cross sectson of only about 5.7 barns, it is seen that the anomaloukly high seatgering for nickel is caused by the $\mathrm{Ni}^{5}$ isotope, in spite of the fact that the scattering by N160 is lower than tho expected potential scatitering.

Both Ni58 and Ni60 are even-eren nusled with presumably zero spin, and hence thelr coherent scattering cross sections should be the same as their total seattering cross sections. Fron transmission measurements on the niekel oxide saxples, the total seattering cross sections for $\mathrm{N1} 58$, $\mathrm{N} 160$, and elamental $\mathrm{NI}$ were determined as 25,3 and 17 barns respectively, as shown in. Table I.

The agreemert between the two cross-section values for Ni58 is alisfactorily within experimental error; while the presence of uncorrected residual water in the $\mathrm{NIO}^{60}$ sapie makes the total scattering larger than the coherent actiering. It would not be expected that the total and coherent seattering. for elemental $\mathrm{Ni}$ should te the same because of isotopic

$$
\text { AECD - } 2359
$$


Table 1. Scattering Cross Sections for Isotopic and Elemental Nickel Samples

$$
\begin{gathered}
\text { Coherent Scattering Total Scattering } \\
\text { Cross Section }
\end{gathered}
$$

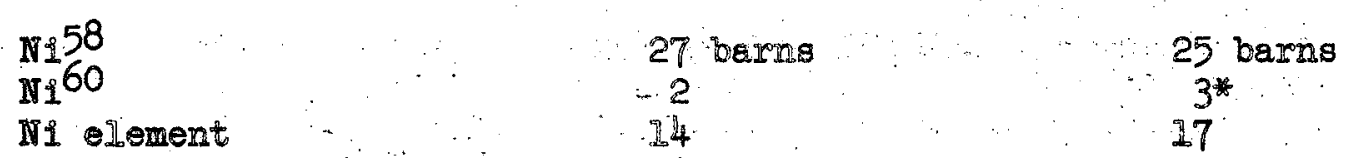

* Not corrected for residual water content in sampio

incohereace A A celculation of tho incoherent scattering to be oxpected for Ni using the above coherent geatiering cross sections for the isotopes leads to a value of 2.7 barns, and this, added to the cohorent scativering, agrees satisfactorily with the total scattering cross section for elemental $N 1$.

The large value for the seattering cross section of $\mathbb{1} 58$, coupled with the fact that this nucleus scatters with positive phase. suggests on the Feshbach Peasleo-Welsekopf picture the prosence or a scattering resonance at a nearby virtual exerg: On tho other hand the smaller-thanexpected scattering cross section for 160 , along with its positive phase of scattering, suggests tho prosencs of a nearby resonace at a higher-thanthermal energy. Havens ot ald have roported evidence for resonance at several hundred volts energy, and this presumably' is to be associated with the $111^{60}$ ingeleus.

\section{SCATMER ING STWDTHS ON WHE ITI ISOTOPES}

The scatbering of nenterons by alemental it has been show by Formi and Marshali, and Wollen and Shuji to occur with a reversed phase of

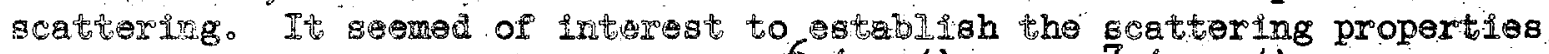

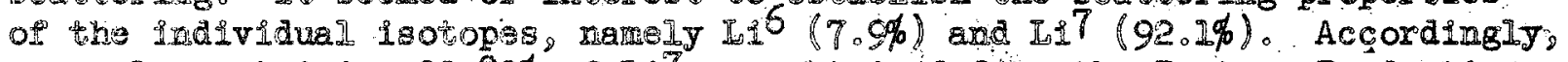
a sample contalning $99.89 \%$ of In 7 obtained form the Isotope Production Divialon at I-1,2, and this wa oxamined in the neutron alfiraction spectromefier in the form of both InTCI and In? tal It were examined for comparison purposes.

Figure 2 howe the spectrometer traces for samples of Iol TCI and IfCI. It Is seen that the (III) reflections are stronger than the (200) reflectich tons por both matorals, and thin indeates that the scattering phase for both If and elementel If is opposite to that of CI. From the peak intensties, lt hes been possibl to calcrlate the coherent scattering cross seotion for In and lomembal If and from these to ovaluate the cross section and phe of scattering for I1.6 These rosults are listod in Table 2. 
Table 2. Scattering Data for the Li Isotopes:

\begin{tabular}{lll}
\hline \hline & Phase of Scattering & $\begin{array}{c}\text { Coherent Scattering } \\
\text { Cross Section }\end{array}$ \\
\hline Ii1 element & negative & $\begin{array}{l}0.4 \text { barns } \\
\text { nogative }\end{array}$ \\
I17 & positive & $\sim 6$ \\
\hline
\end{tabular}

Since the amplitude of scattering for If 7 is more negative than that for olemental Li, it is established that If 6 scatters with a positive phase and with a calculated cross section of about 6 barns. This cross section is uncertain to the extent of perhaps $50 \%$, but the phase of scattering appearsquite definito. Tho negativo scattering amplitude of II7 suggests, according to the Feshbach-Peaslee-Welsskopf theory, that a scattering rosonance occurs for this nucleus at a position somewhat above thermal energies. The small value of the scattering points to an interference between resonance scattering (with nogative phase) and potential scattering (with positive phase), so that the scattering resonance must be located at an energy not too far above thermal, relative to the level spacing. 


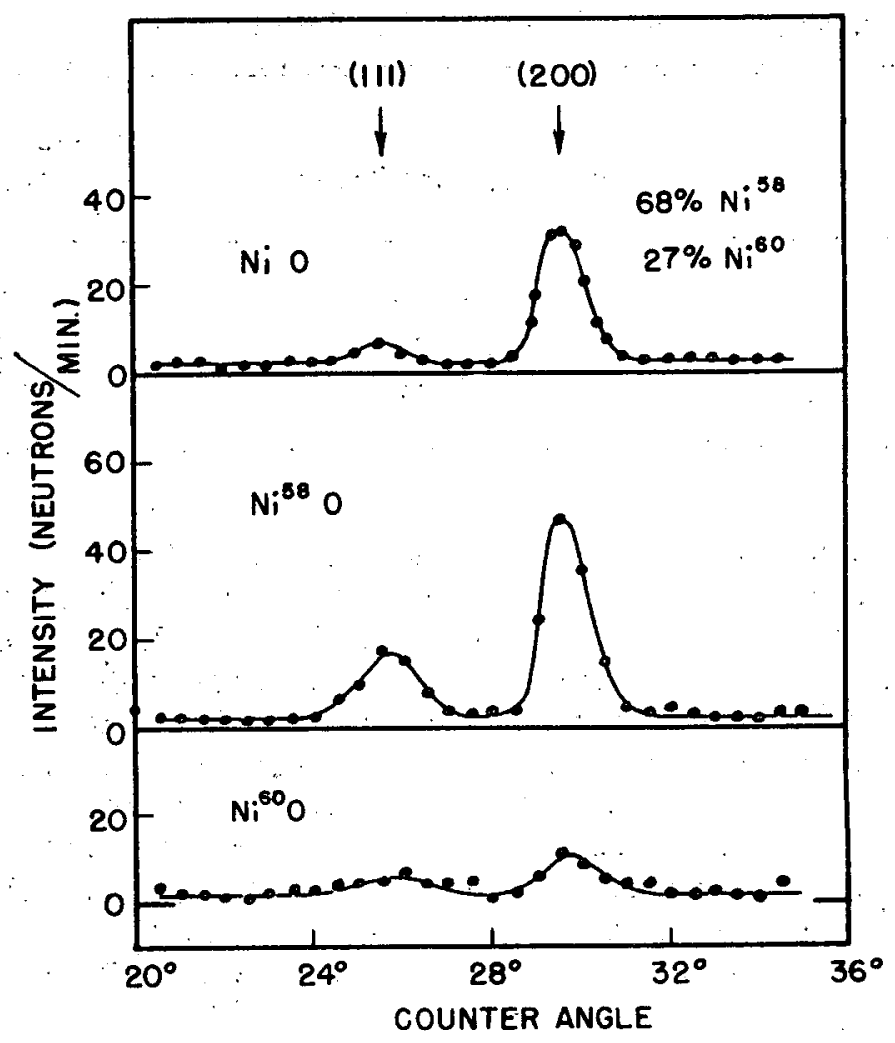

Figure 1.

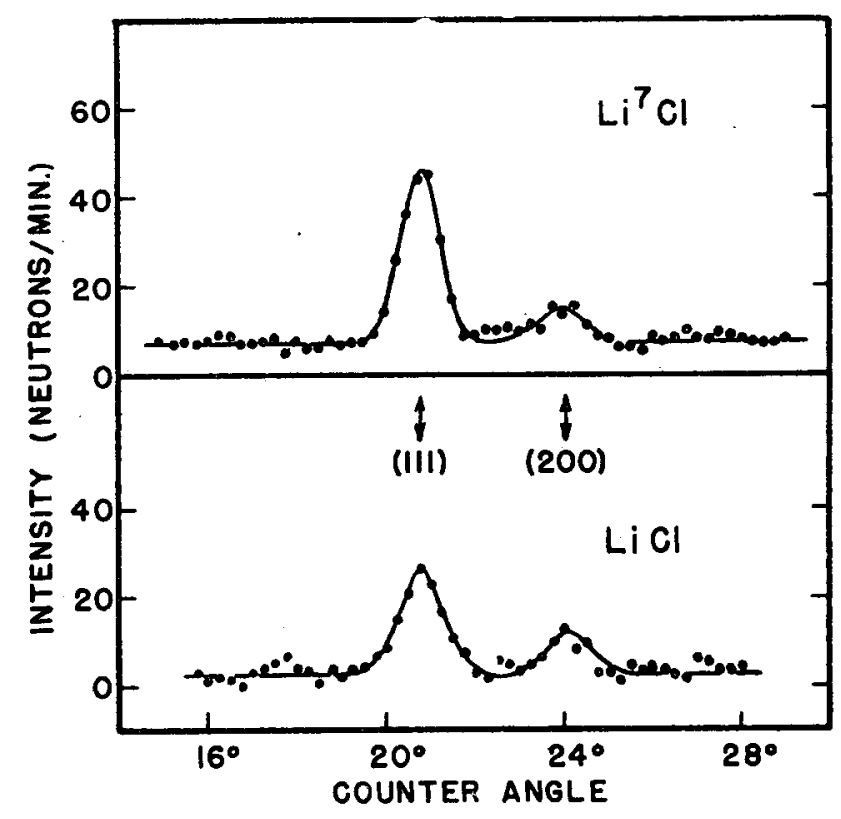

Figure 2.

END OF DOCUMENT 